IRA-International Journal of Education \& Multidisciplinary Studies ISSN 2455-2526; Vol.07, Issue 01 (2017)

Pg. no. 22-26

Institute of Research Advances

http://research-advances.org/index.php/IJEMS

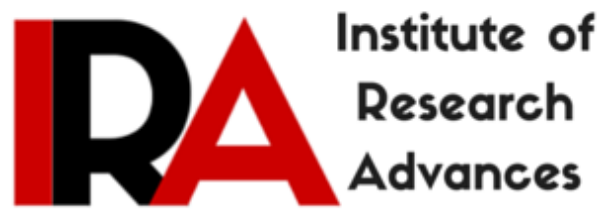

\title{
Mourning Becomes Electra: Morbid Psychology under the "Mask"
}

\section{Gong Yijin}

Xiamen University, Xiamen, Fujian Province, China.

Type of Review: Peer Reviewed.

DOI: http://dx.doi.org/10.21013/jems.v7.n1.p3

\section{How to cite this paper:}

Yijin, G. (2017). Mourning Becomes Electra: Morbid Psychology under the "Mask". IRA International Journal of Education and Multidisciplinary Studies (ISSN 2455-2526), 7(1), 22-26. doi:http://dx.doi.org/10.21013/jems.v7.n1.p3

(C) Author.

\section{(cc) EY-NC}

This work is licensed under a Creative Commons Attribution-Non Commercial 4.0 International License subject to proper citation to the publication source of the work.

Disclaimer: The scholarly papers as reviewed and published by the Institute of Research Advances (IRA) are the views and opinions of their respective authors and are not the views or opinions of the IRA. The IRA disclaims of any harm or loss caused due to the published content to any party. 


\begin{tabular}{|} 
ABSTRACT \\
By giving his main characters all with the "life-like mask", Eugene O'Neill in his play \\
Mourning Becomes Electra aims to reveal the morbid psychology behind that people at that \\
time were facing. O'Neill deepens the tragic effect of excessively emotional self-restraint by \\
intentionally making the conflict happen between family members in a puritanical family, and \\
further making it become a family's doomed and repeated fate. O'Neill presents the awkward \\
situation but he fails to presents the way out; he indeed leaves the remedy to his audience.
\end{tabular}

Key Words: mask; morbid psychology; emotional self-restrain; family; fate.

Eugene O'Neill's play Mourning Becomes Electra is a tragedy which centers itself on a family's walking towards its devastation, with all its family members eventually end up either with death or self-seclusion. At the very beginning of O'Neill's creation, he in his first note for the play asked himself: "is it possible to get modern psychological approximation of Greek sense of fate into such a play, which an intelligent audience of today, possessed of no belief in gods or supernatural, could accept and be moved by"? ( O'Neill, 1926:530) O'Neill's intention for the play is to craft a Greek-like tragedy resulted from a seemingly unavoidable psychological fate. In his play, he considers the psychological fate more of the results of human beings themselves than by supernatural beings as what Greek tragedies might present. It is indeed the tragic morbid psychology men set for themselves that afterwards make them suffer from it, and more miserably, repeat it.

O'Neill reveals the tragic psychological fate in the play by making his characters appear on the stage all with the same "life-like mask", a mask used to hide and pretend their true inner selves. When Lavinia denies the buried secret of her family, Adam Brant boldly accuses her of "liking all Mannons, you're a coward when it comes to facing the truth about themselves"(I.I, p.12). As Brant openly points out, the Mannon family, instead of collapsing from the exterior forces, disintegrates from its inner inherited morbid psychology as a matter of fact. Due to their inborn "life-like masks", it is extremely arduous for a Mannon member to unveil his or her "mask" in order to face the true self, and it is clear that characters in the play are always struggling to restrain their inner feelings. With the suppression of the natural overflow of human feelings, Mannon members are growing increasingly detached and indifferent towards each other, and the "masks" they are walking with seemingly can only be taken of when the fate of family comes to its very end.

The tragic effect of the "life-like mask" is accentuated when Eugene O'Neill directly places the intense conflicts in a puritanical elite family in New England, which traditionally has much emphasis on self-restraint. Though literary critics focus much on O'Neill's denouncement on the puritanical idea, the audience the play targets are not merely those puritans, but the whole public. O'Neill has noticed the wired phenomenon existing in the society and he through his play wants to express his deep concern for the awkward existence human beings are encountering.

The scene of the play is set in a family, intentionally to make the tragedy near to every 
ordinary people, and also this way, achieve what O'Neill has proposed "play accepted and moved by the intelligent audience with no belief in gods and supernatural retribution" at the very beginning (O'Neill, 1926:530). The idea of setting the play in a family can be influenced by O'Neill's two intimate friends G.V. Hamilton and Kenneth Macgowan, who published their collaborated work What is Wrong with Marriage in 1929, investigating the love and sex behavior on the effect of the Puritan conscience. However, O'Neill goes a step further, as he deepens the effect by not merely confining it to be a puritanical tragedy, but making it reflect a general social problem, a "mask-wearing" society.

To present the result of the morbid psychology, partly as his friends did, O'Neill specifically displayed the love-hate relationship between characters in Mannon family, with the rigid marital relationship between Ezra Mannon and his wife Christine being typical. The couple was once the blessed one before marriage, but after their marriage, Christine justifies her hatred for Ezra Mannon, telling Lavinia that "marriage soon turned his romance into -disgust"(I. IV, P.31). The reason for Christine's hatred becomes clearer when she explains to Lavinia that "you were always my wedding night to me -- and my honeymoon"(I. IV, P.31). The haunted image of Ezra Mannon in his portrait reappears many times in the play: a man of great and the great ability to control his feelings and emotion. The war has great influences on the Mannon family, therefore after Ezra's homecoming, he starts to ponder on the issue of death and life. War has made Ezra Mannon reflect on his own life, and it seems that he does realize the hidden tragedy in his seemingly glamorous and dignified life. He has already realized his over emotional suppression, particular his inability to openly utter his love for Christine and their marriage. He at this time tries to alter the situation and be honest to himself. Ezra sincerely confesses to Christine that "It has always been hard for me to talk -- about feelings" and "something queer in me keeps me mum about the things I would like most to say -- keeps me hiding the things I'd like to show" (I.III, P. 23). Though the confession or telling his true inner feelings is extremely challenging, the pent-up detachment in their marriage has already made Christine unable to bear Ezra's sudden and sincere confession, together with his second confession made the next morning before his murder. The marriage is trapped by their long rooted morbid psychology of over-restraining their natural feelings.

The very morbid psychology presented by characters not only shown by their incapability of naturally expressing their inner sentiments, but also embodies in their behaviors of arduously disguising their true feelings in the name of justice. O'Neill in the play applies the word "evil spirit" several times to describe the true inner feelings disguised in most characters. The "evil spirit" disguised in Mannon family specifically are their jealousy and selfishness. Lavinia accuses her mother of adultery with Adam Brant in the name of the family reputation and the puritanical moral, though in fact Lavinia herself is also jealous of her mother's courting with a man she likes, and she later also in the name of justice, encourages her brother Orin to kill Adam. If Lavinia was as obedient as a puritan as she claims herself to be, she would never plot the murder to rob a man's life privately without going through any legal proceedings. Instead, she is more likely to be driven by her personal jealousy to revenge on her mother, and to revenge on Adam's betrayal as well. Jealousy is accompanied with her selfishness; though Lavinia at first knows that the death of Adam will drive her mother to kill herself, she sticks to 
carry out her plan to satisfy her revengeful desire. The murder conducted by Orin is more likely to be prompted by his uncontrolled impulse after witnessing Catherine's adultery with Adam, whom Orin considers shares with him his mother's love. Though Lavinia keeps on persuading Orin that they carry out the murder for justice, Orin at last realizes his own real murder intention, and he never expects that "evil spirit" will drive Catherine to kill herself. Orin can never face his real self that he eventually commits suicide. Lavinia's final self-exile to a life of perpetual exclusion is her final realization of her own "evil spirit".

Eugene O'Neill presents in his play the struggling of these "mask-wearing" characters. On the one side, they are aware of their morbid psychology, and on the other, they are powerless to resist that accustomed mentality. In the play, the often-mentioned place "South Sea" is the dreamed paradise for most Mannon family members, where they believe that they can free themselves from the secular bounds to be themselves. Adam reveals Lavinia's admiration for those islanders, particularly for the fact that "they had found the secret of happiness because they never heard that love can be a sin"(I.I, P.12). Orin when comes back home, discusses a book about the South Sea Island with Catherine and eagerly longs for going there with his mother. Even Ezra himself, once talks about going there with Catherine to resume their marriage. However, the "South Sea" for the Mannon family is more like the "Garden of Eden", which can only be dreamed of but never be arrived at. Neither does Ezra and Catherine witness the Garden, and though Orin and Lavinia have been there, they still remain haunted after their returning back.

Due to their morbid psychology, the Mannon family for the long time keeps haunted, and that even become a family's repeated doomed fate. In his note for the play, O'Neill shows that he deliberately designed his scenes to convey the impression of a fated recurrence. "Repetition of the same scene -- in its essential spirit, sometimes even in its exact words, but between different characters -- following plays as development of fate -- theme demands this repetition" ( O'Neill, 1926:535). Through the use of repetition, O'Neill constantly reminds his audience of the poor situation the characters are trapped in. The audience might find that in the play, scenes such as Orin's final homecoming, greatly resembles to the homecoming of Ezra beforehand. The most prominent instance of this repetition occurs in the third play, in which both Orin and Lavinia turn to be much like their mother and father. Orin even directly utters the situation explicitly:"Can't you see I'm now in Father's place and you're Mother? That's the evil destiny out of the past I haven't dared predict! I'm the Mannon you're chained to!" (III. II, P.155) Orin and Lavinia are at the end the mere copies of their parents. In this respect, the vicious fate seems repeated, which relentlessly passes from one generation to the other.

When Lavinia is away with Orin on the island, Seth bets with his friends for their failure to stay in the vacant and haunted house, and it proves that Seth is right, and the whole town starts to believe that the Mannon house is doomed and haunted. Seth, the old gardener of the Mannon family, set by O'Neill as the outsider and an observer of the family's decline. Though O'Neill does not depict the gardener as elaborately as other characters in Mannon family, it is Seth who raises Lavinia's intense doubt on Adam's real identity, which later promotes the development of the plot. O'Neill crafts the character to raise audience's attention to what's going wrong in the 
so-called upper-class, and in this way, partly conveys his own reflection on the issue of social class.

Through the tragic depiction of a noble family's decline, O'Neill targets to reveal the repeated morbid psychology hidden behind the whole society, and though he himself also tries to tear the "life-like masks" off, the ending of the main female character Electra's complete self-exile can never be promising. The living dilemma is raised by O'Neill, but the real way out remains to be found by the audience.

\section{References}

[1] Barrett H.Clark, rev. ed. "Working Notes and Extracts from a Fragmentary Work Diary" in European Theories of the Drama: With a Supplement on the American Drama. New York, 1947.

[2] Black, Stephen A. Eugene O'Neill: Beyond Mourning and Tragedy. New Haven: Yale University Press, 1999.

[3] Floyd, Virginia. Eugene O 'Neill at Work. New York: Frederick Ungar, 1981.

[4] O'Neill Collection, Beinecke Rare Book and Manuscript Library, Yale University Library: photographs, diaries, notes and clippings.

[5]O'Neill, Eugene. Complete Plays, 1920-1931, ed. Travis Bogard. New York: Library of America, 1988. 